\title{
ФОРМИРОВАНИЕ УНИВЕРСАЛЬНЫХ УЧЕБНЫХ ДЕЙСТВИЙ У ШКОЛЬНИКОВ 11-12 ЛЕТ СРЕДСТВАМИ САМБО
}

\section{FORMATION OF UNIVERSAL EDUCATIONAL ACTIONS FOR PUPILS 11-12 YEARS OLD AT SAMBO CLASSES \\ R. Chernitskiy \\ S. Lepeshkina}

Summary: Introduction. Extracurricular activities within the framework of sambo training contribute to the development of personal qualities in children of 11-12 years old, which is confirmed by many studies. However, the modern system of school education focuses on the formation of universal educational actions that can potentially be developed within the framework of extracurricular sambo lessons, but there is no information in the literature about their effectiveness in this context. Purpose of the study: to determine the influence of extracurricular sambo lessons on the formation of such universal educational actions in schoolchildren of 11-12 years old as: personal, regulatory, cognitive and communicative.

Research methodology and organization. An experimental program for the formation of universal educational actions in children of 11-12 years old has been developed in the framework of extracurricular sambo lessons. The effectiveness of the proposed program was assessed as part of a pedagogical experiment conducted on the basis of the Engineering and Technological Lyceum, Lyubertsy, Moscow Region from September 2019 to March 2020. To assess the effectiveness of the proposed program, we used indicators of the general assessment of the formation of universal educational actions, as well as indicators reflecting the level of development of physical qualities and abilities of schoolchildren.

Research results and their discussion. Schoolchildren of 11-12 years old who attended extracurricular sambo lessons showed a significant increase in the assessment of the personal block of universal educational actions, and also there was a statistically significant increase in indicators reflecting the level of development of physical qualities and abilities. At the end of the pedagogical experiment, schoolchildren attending extracurricular sambo lessons outperform schoolchildren in the control group in all the considered indicators of physical qualities and abilities development.

Conclusions. Extracurricular sambo lessons have a positive effect on the formation of all the main blocks of universal educational actions, which is confirmed by the results of the pedagogical experiment. In addition to effectively promoting the formation of universal educational actions, extracurricular sambo classes have a positive effect on the development of physical qualities and abilities in schoolchildren.

Keywords: sambo, middle school age, extracurricular activities.

\author{
Черницкий Роман Сергеевич \\ Аспирант, ФГБОУ ВО "Московская государственная \\ академия физической культуры" \\ chernitsky2015@mail.ru \\ Лепешкина Светлана Викторовна \\ к.n.н., доцент, ФГБОУ ВО "Московская государственная \\ академия физической культуры" \\ slepeshkina@yandex.ru
}

Аннотация: Введение. Внеурочная деятельность в рамках занятий самбо способствует развитию личностных качеств у детей 11-12 лет, что подтверждается множеством исследований. Однако современная система школьного образования акцентирует внимание на формировании универсальных учебных действий, которые потенциально могут быть развиты в рамках внеурочных занятий самбо, однако в литературе отсутствуют сведения $0 б$ их эффективности в данном контекста.

Цель исследования: определить влияние внеурочных занятий самбо на формирование у школьников 11-12 лет таких универсальных учебных действий, как: личностные, регулятивные, познавательные и коммуникативные.

Методика и организация исследования. Разработана экспериментальная программа формирования универсальных учебных действий у детей 11-12 лет в рамках внеурочных занятий самбо. Оценка эффективности предложенной программы произведена в рамках педагогического эксперимента, проведенного на базе МОУ «Инженерно-технологический лицей» г. Люберцы Московской области с сентября 2019 года по март 2020 года. Для оценки эффективности предложенной программы использованы показатели общей оценка сформированности универсальных учебных действий, а также показатели, отражающие уровень развития физических качеств и способностей школьников.

Результаты исследования и их обсуждение. У школьников 11-12 лет, посещавших внеурочные занятия самбо, произошло достоверное повышение оценки личностного блока универсальных учебных действий, а также произошел статистически достоверный прирост показателей отражающих уровень развития физических качеств и способностей. На момент завершения педагогического эксперимента, школьники посещающие внеурочные занятия самбо превосходят школьников контрольной группы по всем рассматриваемым показателям развития физических качеств и способностей.

Выводы. Внеурочные занятия самбо положительно сказываются на формировании всех основных блоков универсальных учебных действий, что подтверждается результатами педагогического эксперимента. Помимо эффективного содействия формированию универсальных учебных действий, внеурочные занятия самбо положительно сказываются на развитии физических качеств и способностей у школьников.

Ключевые слова: самбо, средний школьный возраст, внеурочные занятия. 


\section{Введение}

Согласно ФГОС, внеурочная деятельность играет важную роль в развитии личности по таким направлениям, как: духовно-нравственное; физкультурно-спортивное и оздоровительное; социальное; обще-интеллектуальное; общекультурное. Большую популярность получают внеурочные занятия, основанные на единоборствах, в особенности "Самбо". Самбо является высокоэффективной формой внеурочных занятий, способных оказывать выраженное влияние на развитие личностных и физических качеств детей на всем протяжении освоения общеобразовательной школьной программы [3, 4]. Внеурочные занятия самбо, органично дополняют обязательную часть общеобразовательной программы благодаря сочетанию в себе базовых элементов физической культуры и специфических черт спортивной борьбы [1]. Несмотря на достаточную степень раскрытия вопросов влияния занятий самбо на личность детей 11-12 лет, эффективность данных занятий в контексте реализации ФГОС в научной и методической литературе не раскрыта должным образом. Актуальность исследования базируется на необходимости изучения эффективности формирования универсальных учебных действий в контексте реализации ФГОС у школьников 11-12 лет на внеурочных занятиях самбо. Цель исследования - определить влияние внеурочных занятий самбо на формирование у школьников 11-12 лет таких универсальных учебных действий, как: личностные, регулятивные, познавательные и коммуникативные.

\section{Методика}

Исследование вопросов формирования универсальных учебных действий школьников 11-12 лет в условиях внеурочных занятий самбо предполагало проведение педагогического эксперимента. Эксперимент проведен с сентября 2019 г. по март 2020 г., на базе МОУ «Инженерно-технологический лицей» г. Люберцы Московской области. На основании факта посещения внеурочных занятий самбо, сформировано две выборки испытуемых: контрольная $(n=20$, школьники, не посещавшие внеурочных занятий); экспериментальная $(\mathrm{n}=20$, школьники посещавшие внеурочные занятия самбо). Таким образом, в педагогическом эксперименте приняло участие 40 учеников 5-6 классов (11-12 лет). Школьный учебный план учеников контрольной и экспериментальной группы не имел отличий. Оценка уровня сформированности универсальных учебных действий школьников осуществлялась на основании критериев, приведенных Э.Ф. Насыровой и Н.Л. Васениной [5, с. 115]. Внеурочные занятия самбо оказывают выраженное влияние на уровень физического развития детей. Влияние занятий самбо на физические способности детей требует рассмотрения данных показателей при изучении формирования универсальных учебных действий у школьников. Диа- гностика физических способностей осуществлена благодаря проведению педагогического тестирования, в рамках которого использовались тесты, представленные во Всероссийском физкультурно-спортивном комплексе «Готов к труду и обороне» (3 ступень) [2] + тесты на определение силы, быстроты, гибкости. На момент начала и завершения педагогического эксперимента проводилось педагогическое тестирование физических способностей школьников контрольной и экспериментальной группы, а также исследовался уровень сформированности УУД. Обработка данных, полученных в исследовании выполнена в программе Microsoft Excel. По результатам математико-статистической обработки получены следующие показатели: среднее-арифметическое; р- достоверность различий. Определение достоверности различий осуществлялось при помощи: парного двухвыборочного t-теста для средних, при сравнении выборок связанных данных; двухвыборочного t-теста с одинаковыми или различными дисперсиями при сравнении несвязанных выборок данных.

Учебный план внеурочных занятий самбо с экспериментальной группой представлен в таблице 1.

\section{Результаты и их обсужАение}

Исходные показатели, полученные путем педагогического тестирования, не имеют межгрупповых статистически достоверных различий(р>0,05). Таким образом, сделано заключение о том, что обе выборки школьников обладают идентичным уровнем физического развития. Оценка изменения в развитии физических способностей школьников осуществлена путем сравнения разницы, полученной при вычитании заключительного значения из исходного (Таблица 2.).

Как видно из представленных в таблице 2 значений, изменения произошли в обеих группах испытуемых. Произошедшие изменения обусловлены как возрастными особенностями биологического развития, так и присутствием в общеобразовательной программе уроков физической культуры, обладающих разносторонним содержанием. Межгрупповое сравнение результатов, полученных при заключительном тестировании, показало статистически достоверное $(p<0,05)$ преобладание всех представленных в таблице 2 показателей экспериментальной группы, над показателями контрольной группы. Что же касается статистической достоверности изменений, произошедших в контрольной группе, то следует отметить наличие статистической достоверности $(\mathrm{p}<0,05)$ лишь по 6-ти показателям из 12. При сопоставлении изменений, произошедших в обеих группах, наибольшие изменения отмечены у школьников экспериментальной группы, посещавших внеурочные занятия самбо. В экспериментальной группе выявлена статистическая достоверность изменений $(p<0,05)$ по всем 
Таблица 1.

Учебный план внеурочных занятий самбо экспериментальной групп.

\begin{tabular}{|c|c|c|c|}
\hline № & Раздел программы & Кол-во часов & Содержание раздела \\
\hline 1 & Теоретическая подготовка & 6 & $\begin{array}{l}\text { Краткий обзор истории развития самбо; Краткие сведения о влиянии физических нагрузок на } \\
\text { организм; Гигиена, врачебный контроль, предупреждение травм; Основы техники и тактики } \\
\text { самбо; Правила соревнований }\end{array}$ \\
\hline 2 & $\begin{array}{l}\text { Общая и специальная физиче- } \\
\text { ская подготовка }\end{array}$ & 28 & $\begin{array}{l}\text { Общая физическая подготовка (ОРУ, подвижные игры, акробатические упражнения), специ- } \\
\text { альные упражнения (подводящие упражнения, акробатические упражнения). }\end{array}$ \\
\hline 3 & Технико-тактическая подготовка & 36 & 0бучение технике и тактике самбо \\
\hline 4 & Участие в соревнованиях & 4 & Соревнования по самбо по облегченным правилам \\
\hline 5 & Контрольные испытания & 2 & Блок контрольных испытаний \\
\hline \multicolumn{2}{|r|}{ Общее количество часов } & 76 & \\
\hline
\end{tabular}

Таблица 2.

Изменения показателей физических способностей учащихся контрольной и экспериментальной группы.

\begin{tabular}{|l|c|c|}
\multirow{2}{*}{\multicolumn{1}{c|}{ Показатель }} & \multicolumn{2}{|c|}{ Разность исходных и заключительных результатов } \\
\cline { 2 - 3 } & КГ & $0,94^{*}$ \\
\hline Бег на 60 метров & $0,27^{*}$ & $-33,2^{*}$ \\
\hline Прыжок в длину с места & $-19,8^{*}$ & $0,58^{*}$ \\
\hline Челночный бег & $0,14^{*}$ & $-6,38^{*}$ \\
\hline Метание мяча & $-2,41^{*}$ & $49,95^{*}$ \\
\hline Бег на 1500 метров & $6,75^{*}$ & $-2,6^{*}$ \\
\hline Подтягивание из виса на высокой перекладине & $-0,64$ & $-8,2^{*}$ \\
\hline Поднимание туловища из положения лежа & $-3,3^{*}$ & $-2,6^{*}$ \\
\hline Выпрыгивание из приседа & $-0,45$ & $-3,2^{*}$ \\
\hline Сгибание и разгибание рук в упоре лежа & $-1,5$ & $-4,35^{*}$ \\
\hline Кистевая динамометрия правой руки & $-0,3$ & $-1,1^{*}$ \\
\hline Кистевая динамометрия левой руки & $-0,25$ & $-1,8^{*}$ \\
\hline Наклон вперед из положения стоя & $-0,69$ & \\
\hline
\end{tabular}

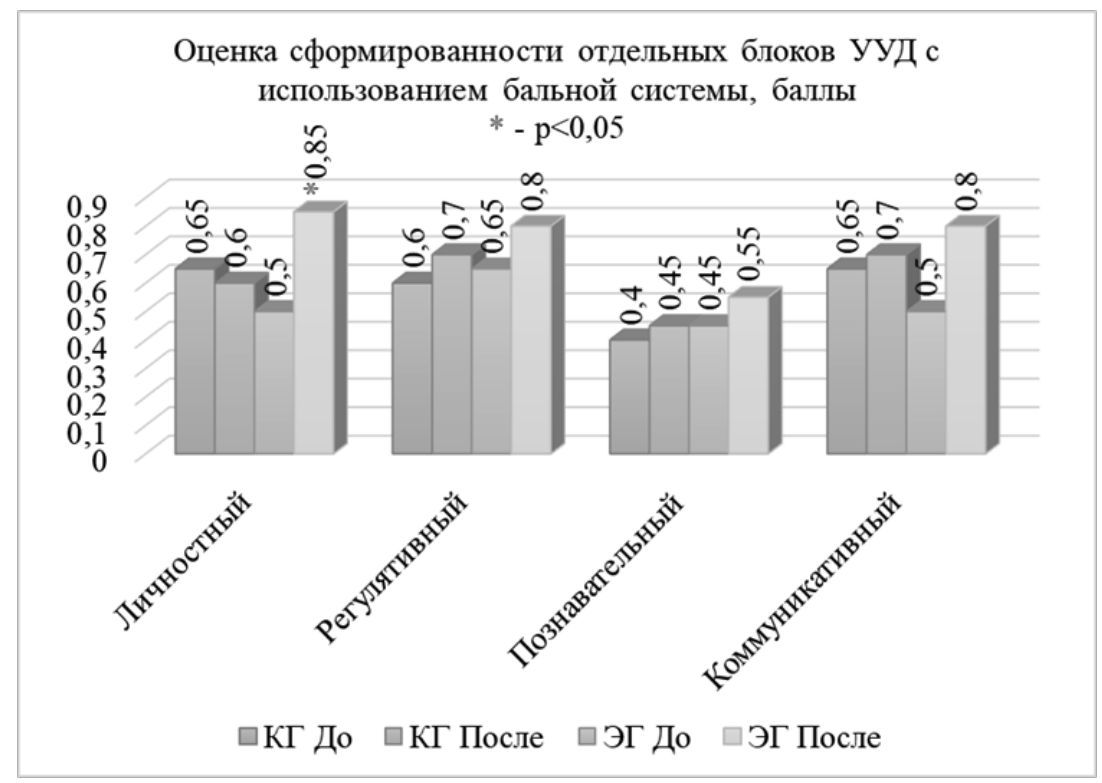

Рис. 1. Сформированность отдельных блоков УУД у контрольной и экспериментальной групп до и после проведения педагогического эксперимента. 
приведенным в таблице 2 показателям. Соответственно, мы делаем заключение о том, что внеурочные занятия самбо оказывают выраженное и положительное влияние на физические способности школьников 11-12 лет.

Рассматривая уровень сформированности УУД (Э.Ф. Насырова, Н.Л. Васенина, 2016) у школьников 11-12 лет, необходимо отметить, что на момент начала педагогического эксперимента, между контрольной и экспериментальной группами школьников отсутствуют статистически достоверные различия ( $>>0,05)$. Результаты оценки уровня сформированности отдельных блоков УУД представлены графически на рисунке 1.

На рисунке 1 отчетливо проиллюстрированы изменения, произошедшие в обеих выборках в оба момента исследования. Изменения, произошедшие в контрольной группе, носят не однозначный характер и не имеют статистической достоверности $(p<0,05)$. Для школьников экспериментальной группы, посещавших внеурочные занятия самбо, характерна положительная тенденция в виде повышения уровня сформированности всех рассматриваемых блоков универсальных учебных действий. Для экспериментальной группы также характерна статистическая достоверность $(p<0,05)$ произошедших изменений в следующих блоках уУД: личностный, регулятивный, коммуникативный. На момент завершения педагогического эксперимента, у экспериментальной группы отмечаются более высокий уровень сформированности УУД по отношению к контрольной группе. Сформированность личностного блока УУД на момент завершения педагогического эксперимента статистически достоверно $(p<0,05)$ более высока чем у контрольной группы.

\section{Выводы}

Экспериментальным путем продемонстрирована эффективность внеурочных занятий самбо в формировании универсальных учебных действий школьников 11-12 лет. Занятия самбо обеспечивают не только развитие двигательных способностей школьников, но и способствуют формированию личностного, регулятивного, познавательного и коммуникативного блоков универсальных учебных действий. На основании результатов исследования можно рекомендовать занятия самбо в качестве внеурочной формы занятий в контексте реализации ФГОС.

\section{ЛИТЕРАТУРА}

1. Антонюк С.Д. Реализация инновационной программы «самбо в школу» в рамках учебного предмета «физическая культура» в условиях реализации федерального государственного образовательного стандарта / С.Д. Антонюк, И.В. Кожевникова // Вестник Тамбовского университета. Серия: Гуманитарные науки. - 2016. - Т. 21. - №. 9 (161). С. 50-57.

2. Виноградов П.А. Всероссийский физкультурно-спортивный комплекс «Готов к труду и обороне» (ГТО) - путь к здоровью и физическому совершенству: Общее / П.А. Виноградов, А.В. Царик, Ю.В. Окуньков. - Москва: Спорт, 2016. - 234 с.

3. Лукин А.А. Борьба самбо. Вариативная часть физической культуры: учебно-методическое пособие для студентов и преподавателей / А.А. Лукин, Г.П. Галочкин, Н.В. Щетинин. - Воронеж: Воронежский государственный архитектурно-строительный университет, ЭБС АСВ, 2016.50 с.

4. Лукин С.А. Взаимосвязь развития прикладных навыков и физических качеств на уроке самбо у детей 11-12 лет (Учащихся 5-х классов) / С.А. Лукин, С.Е. Табаков // Боевые искусства и спортивные единоборства: Наука, практика, воспитание: материалы III Всероссийской научно-практической конференции с международным участием. 2018. С. 156-160.

5. Насырова Э.Ф. Оценка сформированности универсальных учебных действий учащихся в ходе проектной деятельности на уроках технологии / Э.Ф. Насырова, Н.Л. Васенина // Наука и школа. 2016. №4. С. 112-117.

() Черницкий Роман Сергеевич (chernitsky2015@mail.ru), Лепешкина Светлана Викторовна (slepeshkina@yandex.ru). Журнал «Современная наука: актуальные проблемы теории и практики» 